\title{
IMPLEMENTASI METODE WATERFALL DALAM MEMBANGUN TRACER STUDY DAN PENERIMAAN PESERTA DIDIK BARU DENGAN PENGUJIAN BLACK BOX TESTING
}

\author{
Mukrodin $^{1}$, Sugiamto ${ }^{2}$ \\ ${ }^{1}$ Jurusan Sistem Informasi, Fakultas Sains dan Teknologi Universitas Peradaban \\ ${ }^{2}$ Program Studi Sistem Informasi, Fakultas Teknologi Informasi, Universitas Stikubank \\ ${ }^{1}$ mukrodins@gmail.com, ${ }^{2}$ sugiyamtagik@edu.unisbank.ac.id
}

\begin{abstract}
Abstrak
SMK.S Al Habibatain Bumiayu merupakan salah satu SMK swasta di Kabupaten Brebes yang memiliki dua program studi yaitu Teknik Komputer Jaringan dan Teknik Sepeda Motor, selama ini aktifitas pengelolaan data siswa yang dilakukan di sekolah masih menggunakan pelayanan manual bahkan sekolah tersebut belum memiliki website termasuk dalam pendafataran mahasiswa baru dan penelusuran alumni (tracer Study). Hal ini membuat pelayanan menjadi lambat dan sulit untuk menelusuri para alumni yang sudah bekerja ataupun yang sedang kuliah. Dari persoalan yang ada, maka peneliti berinisiatif melakukan penelitian untuk membangun dan mengembangkan sistem informasi sekolah dengan menerapkan metode waterfall untuk meningkatkan pelayanan yang selama ini masih lambat dalam pengolahan data pendaftaran dan tracer study. Metode waterfall adalah metode yang bersifat sistematis dan berurutan dalam membangun sebuah software yang menarik dan mudah digunakan, waterfall juga sering disebut dengan classical life cycle. Sehingga metode waterfall sangat cocok dalam membangun aplikasi yang baru dan juga dalam pengembangan aplikasi dengan tingkat resiko yang kecil serta waktu pengembangan yang relative cukup cepat sehingga mampu meningkatkan kecepatan dan ketepatan dalam pengolahan data pendaftaran dan tracer study.
\end{abstract}

Kata Kunci: Waterfall, Penerimaan Peserta Didik Baru, tracer study, SMK

\section{PENDAHULUAN}

Perkembangan Teknologi informasi dan komunikasi semakin pesat dan cepat sejak munculnya teknologi internet hal ini sangat membantu dalam kemudahan serta kecepatan pengiriman, penyampaian dan penerimaan informasi. Mulai dari perusahaan, sekolah, perguruan tinggi, dan lembaga atau organisasi lainnya telah banyak memanfaatkan aplikasi berbasis website dalam kegiatan penjualan, promosi, belajar dan kegiatan lainnya dimana dibutuhkan pengiriman, penyebaran dan penerimaan informasi sehingga memberikan kemudahan bagi pengguna (user) yang membutuhkan.

Aplikasi webite atau bisa disebut juga dengan perangkat lunak berbasis website telah berkembang dengan pesat baik dari segi penggunaan, ukuran, bahasa yang digunakan dan kompleksitasnya. Aplikasi website pada mulanya hanya berupa situs website yang bersifat statis, serta lebih banyak digunakan sebagai brosur produk atau profil perusahaan online. Pada saat ini aplikasi website telah banyak yang bersifat dinamis, interaktif dan task oriented untuk digunakan dalam sistem informasi, telekomunikasi, perdagangan, perbankan dan lain-lain.

SMK.S Al Habibatain Bumiayu Kabupaten Brebes Jawa Tengah, selama ini belum memiliki sistem informasi maupun website sekolah sendiri yang dapat diakses dengan mudah oleh masyarakat umum dan warga sekolah terutama berkaitan dengan pendaftaran siswa baru, serta pelacakan lulusan yang ada. Sehingga informasi mengenai beberapa program yang berada di SMK tersebut masih sangat kurang. Dari permasalahan yang ada, maka penulis membuat sebuah sistem informasi akademik yang bisa melakukan pelacakan alumni, pendaftaran siswa baru secara online dengan menggunakan metode waterfall dalam pengembangannya. Dengan 
harapan dengana pembangunan sistem informasi akademik ini dapat membantu masyarakat dan warga sekolah mengakses informasi mengenai SMK.S Al Habibatain Bumiayu dengan cepat, mudah, dan efisien, dan dapat dilakukan di manapun.

\section{TINJAUAN PUSTAKA}

Tinjuan Pustaka adalah ulasan mengenai penelitian yang terdahulu dan memiliki kemiripan baik ojek atau permasalahan, yang bisa jadi ada kaitanya dengan penelitian yang sedang dilakukan, penelitian tersebut bisa berupa jurnal, skripsi, tesis atau desertai :

Tabel 1. Perbadingan Penelitian terdahulu dan penelitian sekarang

\begin{tabular}{|c|c|c|c|c|c|}
\hline No. & Peneliti & Jurnal & Judul & Persamaan & Perbedaan \\
\hline 1. & $\begin{array}{l}\text { Regi } \\
\text { Witanto, } \\
\text { dan Hanhan } \\
\text { Hanafiah } \\
\text { Solihin }\end{array}$ & $\begin{array}{l}\text { Jurnal } \\
\text { Infotronik, } \\
\text { Volume } 1 \\
\text { No. 1, } \\
\text { Desember } \\
2016\end{array}$ & $\begin{array}{l}\text { Perancangan Sistem } \\
\text { Informasi } \\
\text { Penerimaan Siswa } \\
\text { Baru Berbasis Web } \\
\text { (Studi Kasus : Smp } \\
\text { Plus Babussalam } \\
\text { Bandung) }\end{array}$ & $\begin{array}{l}\text { Persamaan } \\
\text { Membangun } \\
\text { Sistem } \\
\text { Penerimaan } \\
\text { Siswa Baru } \\
\text { Dan Berbasis } \\
\text { Website }\end{array}$ & $\begin{array}{l}\text { Objek } \\
\text { Penelitian, } \\
\text { Sistem Yang } \\
\text { Bagun Lebih } \\
\text { Dari Satu Yaitu } \\
\text { Ada Sistem } \\
\text { Pelcakan } \\
\text { Alumni }\end{array}$ \\
\hline 2. & $\begin{array}{l}\text { Margareta } \\
\text { Nawang, } \\
\text { Laela } \\
\text { Kurniawati, } \\
\text { dan Dudi } \\
\text { Duta }\end{array}$ & $\begin{array}{l}\text { Jurnal } \\
\text { PILAR } \\
\text { Nusa } \\
\text { Mandiri, } \\
\text { Volume 13 } \\
\text { No. 2, } \\
\text { September } \\
2017\end{array}$ & $\begin{array}{l}\text { Rancang Bangun } \\
\text { Sistem Informasi } \\
\text { Pengolahan Data } \\
\text { Persediaan Barang } \\
\text { Berbasis Dekstop } \\
\text { Dengan Model } \\
\text { Waterfall }\end{array}$ & $\begin{array}{l}\text { Persamaan } \\
\text { Sama-Sama } \\
\text { Menggunakan } \\
\text { Model } \\
\text { Waterfall } \\
\text { Dalam } \\
\text { Pengembangan }\end{array}$ & $\begin{array}{l}\text { Data Yang } \\
\text { diolah dan } \\
\text { Sistem yang } \\
\text { dibangun } \\
\text { berbeda : } \\
\text { Berbasis } \\
\text { Website dan } \\
\text { objeknya SMK }\end{array}$ \\
\hline 3. & $\begin{array}{l}\text { Nuryake } \\
\text { Fajaryati } \\
\text { dkk. }\end{array}$ & $\begin{array}{l}\text { Jurnal } \\
\text { Teknologi, } \\
\text { Volume } 6 \\
\text { No. } 1 \text { Juni } \\
2016\end{array}$ & $\begin{array}{l}\text { Studi Penelusuran } \\
\text { (Tracer Study) } \\
\text { Terhadap Alumni } \\
\text { Program Studi } \\
\text { Pendidikan Teknik } \\
\text { Informatika Jurusan } \\
\text { Pendidikan Teknik } \\
\text { Elektronika Fakultas } \\
\text { Teknik Universitas } \\
\text { Negeri Yogyakarta }\end{array}$ & $\begin{array}{l}\text { Sama-sama } \\
\text { Meneliti } \\
\text { Tentang } \\
\text { Penelusuran } \\
\text { Alumni Dan } \\
\text { Sistem Yang } \\
\text { Dibangun } \\
\text { Berbasis } \\
\text { Website }\end{array}$ & $\begin{array}{l}\text { Sistem yang } \\
\text { dibangun lebih } \\
\text { dari satu yaitu } \\
\text { ada sistem } \\
\text { pendaftaran } \\
\text { siswa baru }\end{array}$ \\
\hline
\end{tabular}

\section{METODE PENELITIAN}

\subsection{Metode Pengembangan Sistem}

Metode penelitian yang diterapkan pada penelitian ini adalah dengan pengembangan metode waterfall. Metode waterfall merupakan model pengembangan sistem informasi yang terstruktur dan berurutan. 


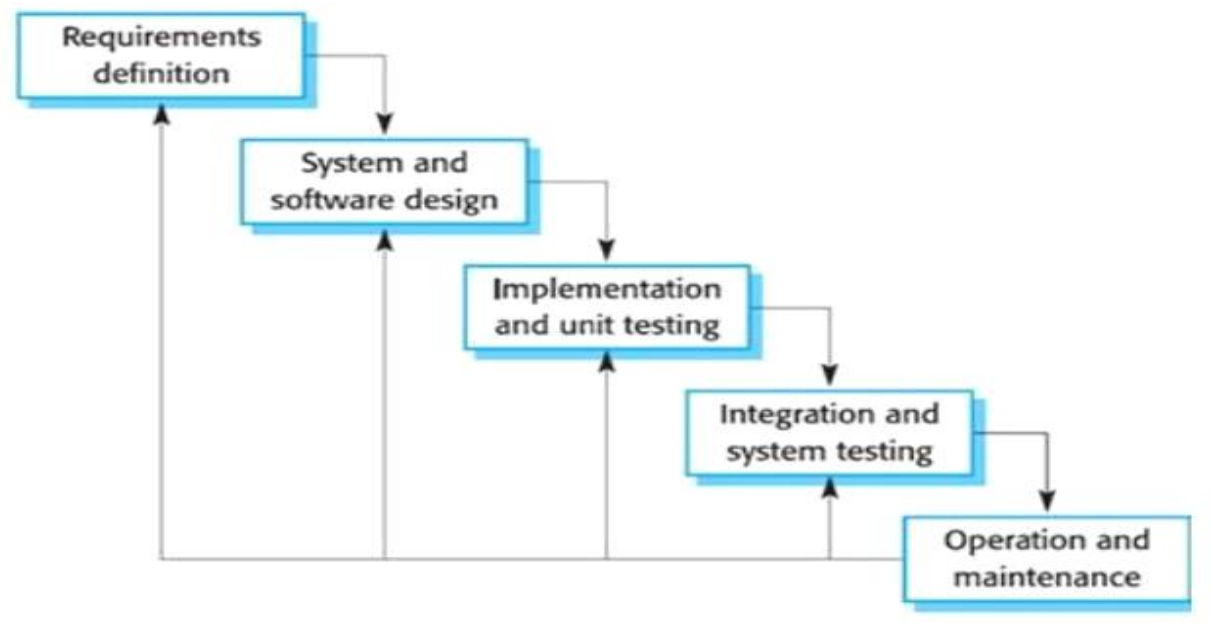

Gambar 1. Bagan waterfall

Metode Waterfall memiliki tahapan-tahapan sebagai berikut:

a. Requirements analysis and definition

Layanan sistem, kend1ala, dan tujuan ditetapkan oleh hasil konsultasi dengan pengguna yang kemudian didefinisikan secara rinci dan berfungsi sebagai spesifikasi sistem.

b. System and software design

Tahapan perancangan sistem mengalokasikan kebutuhan-kebutuhan sistem baik perangkat keras maupun perangkat lunak dengan membentuk arsitektur sistem secara keseluruhan. Perancangan perangkat lunak melibatkan identifikasi dan penggambaran abstraksi sistem dasar perangkat lunak dan hubungannya.

c. Implementation and unit testing

Pada tahap ini, perancangan perangkat lunak direalisasikan sebagai serangkaian program atau unit program. Pengujian melibatkan verifikasi bahwa setiap unit memenuhi spesifikasinya.

d. Integration and system testing

Unit-unit individu program atau program digabung dan diuji sebagai sebuah sistem lengkap untuk memastikan apakah sesuai dengan kebutuhan perangkat lunak atau tidak. Setelah pengujian, perangkat lunak dapat dikirimkan ke customer

e. Operation and maintenance

Biasanya (walaupun tidak selalu), tahapan ini merupakan tahapan yang paling panjang. Sistem dipasang dan digunakan secara nyata. Maintenance melibatkan pembetulan kesalahan yang tidak ditemukan pada tahapan-tahapan sebelumnya, meningkatkan implementasi dari unit sistem, dan meningkatkan layanan sistem sebagai kebutuhan baru.

\subsection{Perancangan Sistem}

Perancangan sistem adalah merancang atau medesain suatu aplikasi sistem yang baik yang isinya adalah langkah-langkah operasi dalam proses pengolahan data proses dan prosedur-prosedur untuk mendukung operasi sistem.

\subsubsection{Entity Relationship Diagram (ERD)}

Entity relationship Model merupakan suatu model data yang dikembangkan berdasarkan objek. $E R \_M$ digunakan uuntuk menjelaskan hubungan antar data dalam basis data kepada pemakai secara logika. ER_M didasarkan pada suatu persepsi bahwa real word terdiri atas obyek-obyek dasar yang mempunyai hubungan/kerelasian antar obyek-obyek dasar tersebut. $E R \_M$ digambarkan dalam bentuk diagram yang disebut diagram ER (ER_Diagram/ER_D) dengan menggunakan simbol-simbol grafis tertentu. Model ini juga membantu perancang basis data dalam melakukan analisis dan perancangan basis data karena model ini dapat 
menunjukan macam data yang dibutuhkan dan kerelasian antar data di dalamanya. Sebuah diagram ER/ER_D tersusun ada tiga komponen, yaitu entitas, atribut, keselerasian antar entitas, dan alur. Secara garis besar entitas merupakan objek dasar yang terlibat dalam sistem.

Atribut berperan sebagai penjelas entitas, dan keselerasian menunjukan hubungan yang terjadi diantara dua entitas, sedangkan alur berfungsi untuk menghubungkan atribut dengan entity dan entitas dengan relasi (Sutanta, 2004).Berikut ini merupakan perancangan ERD Pendaftaran Siswa baru dan Pelacakan Alumni SMK.S Al Habibatain Bumiayu digambarkan sebagai berikut:

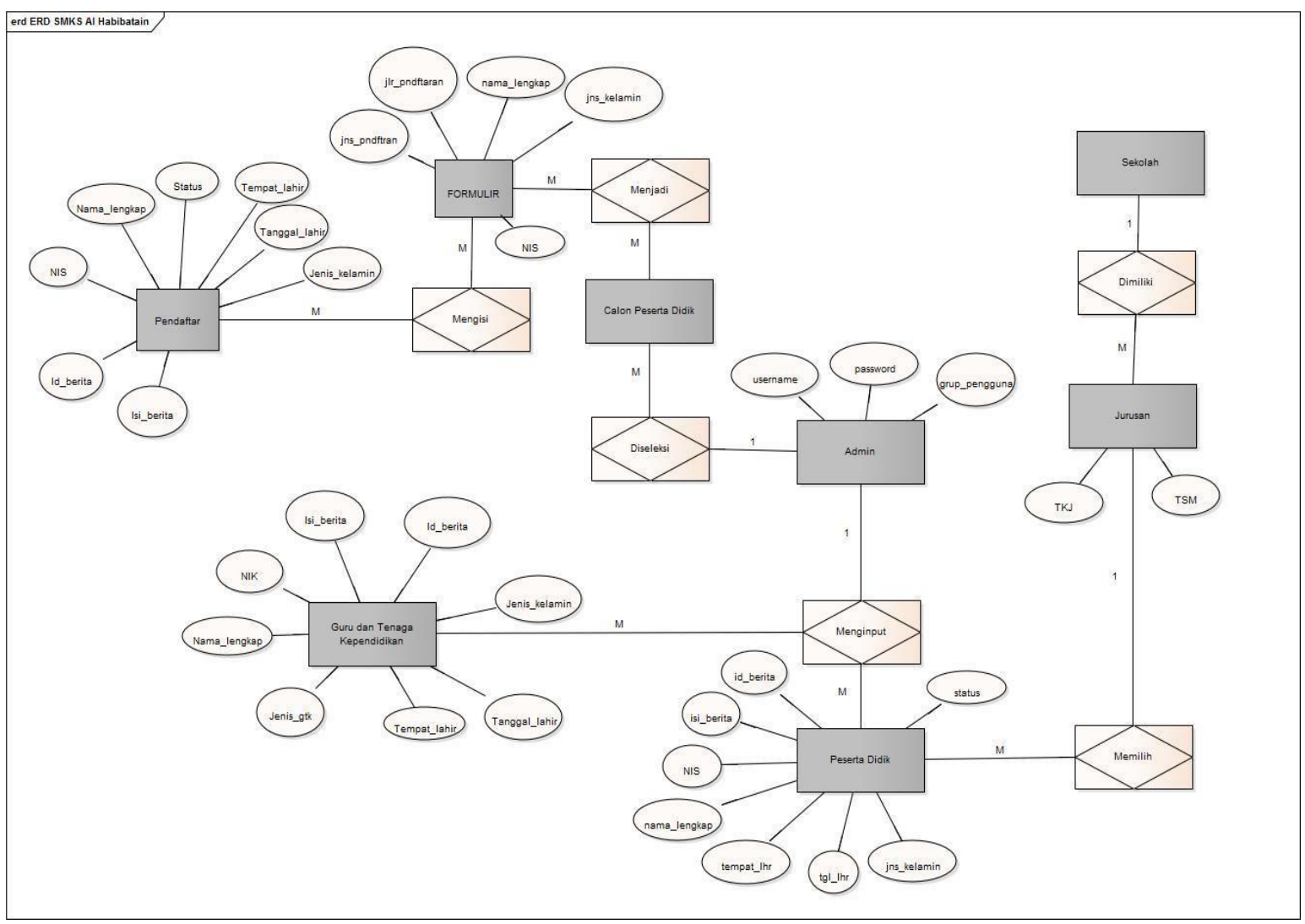

Gambar 2. ERD Pendaftaran Siswa baru dan Pelacakan Alumni

\subsubsection{Unified Modeling Language (UML)}

UML yang berarti bahasa pemodelan standar. Ketika kita membuat model menggunakan konsep UML ada aturan-aturan yang harus diikuti. Bagaimana elemen pada model-model yang kita buat berhubungan satu dengan yang lainnya harus mengikuti standar yang ada. UML bukan hanya sekedar diagram tetapi juga menceritakan konteksnya. (Pudjo Prabowo.Herlawati, 2013). UML diaplikasikan untuk maksud tertentu biasanya antara lain: Merancang Perangkat Lunak, Sarana Komunikasi antara perangkat lunak dengan proses bisnis, Menjabarkan sistem secara rinci untuk analisa dan mencari apa yang diperlukan system, Mendokumentasi sistem yang ada, proses-proses dan organisasinya.

a. Use Case Diagram berikut :

Diagram use case dari PPDB sekolah SMK.S Al Habibatain Bumiayu adalah sebagai 


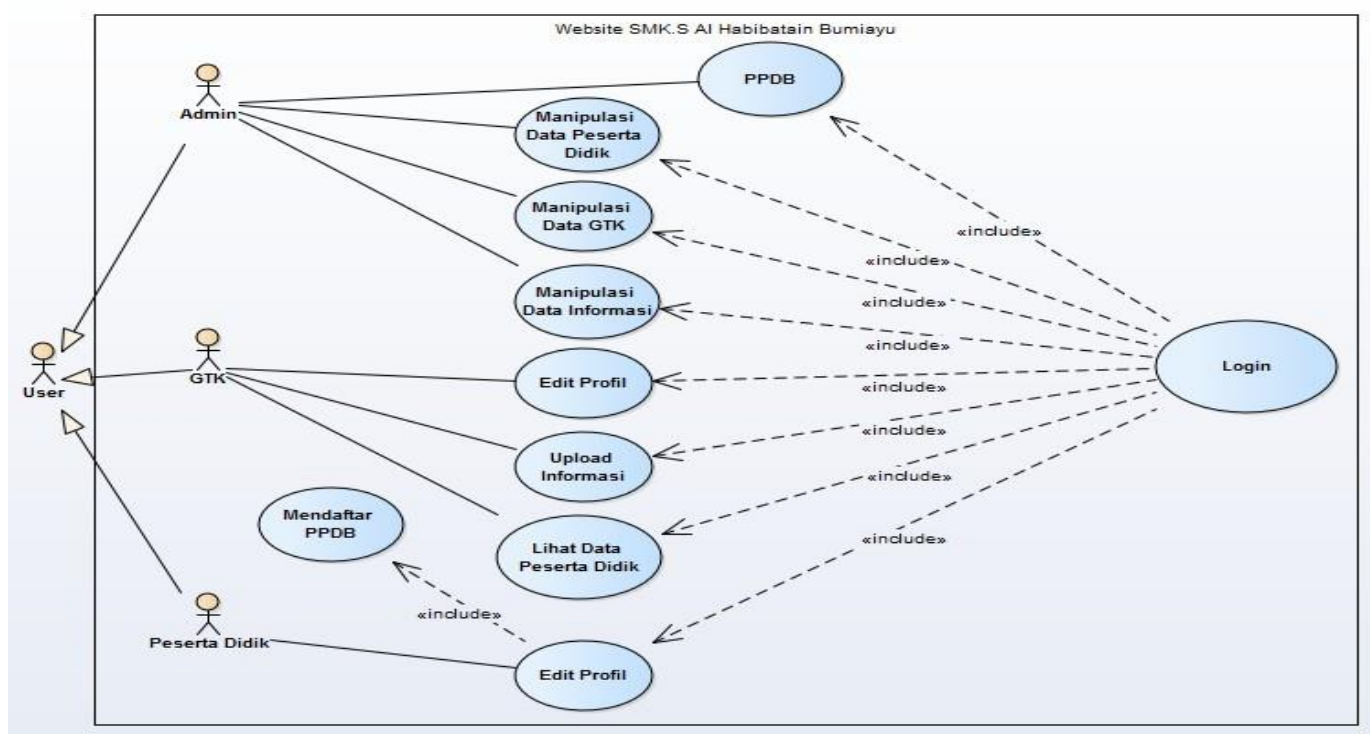

Gambar 3. Use case Diagram PPDB SMK Al Habibatain Bumiayu

\section{b. Activity Diagram Use Case Login}

Activity Diagram adalah salah satu cara untukmemodelkan event-event yang terjadi dalam suatu Use Case. Activity Diagram berikut menggambarkan proses Login admin terhadap isi web sebagai berikut :

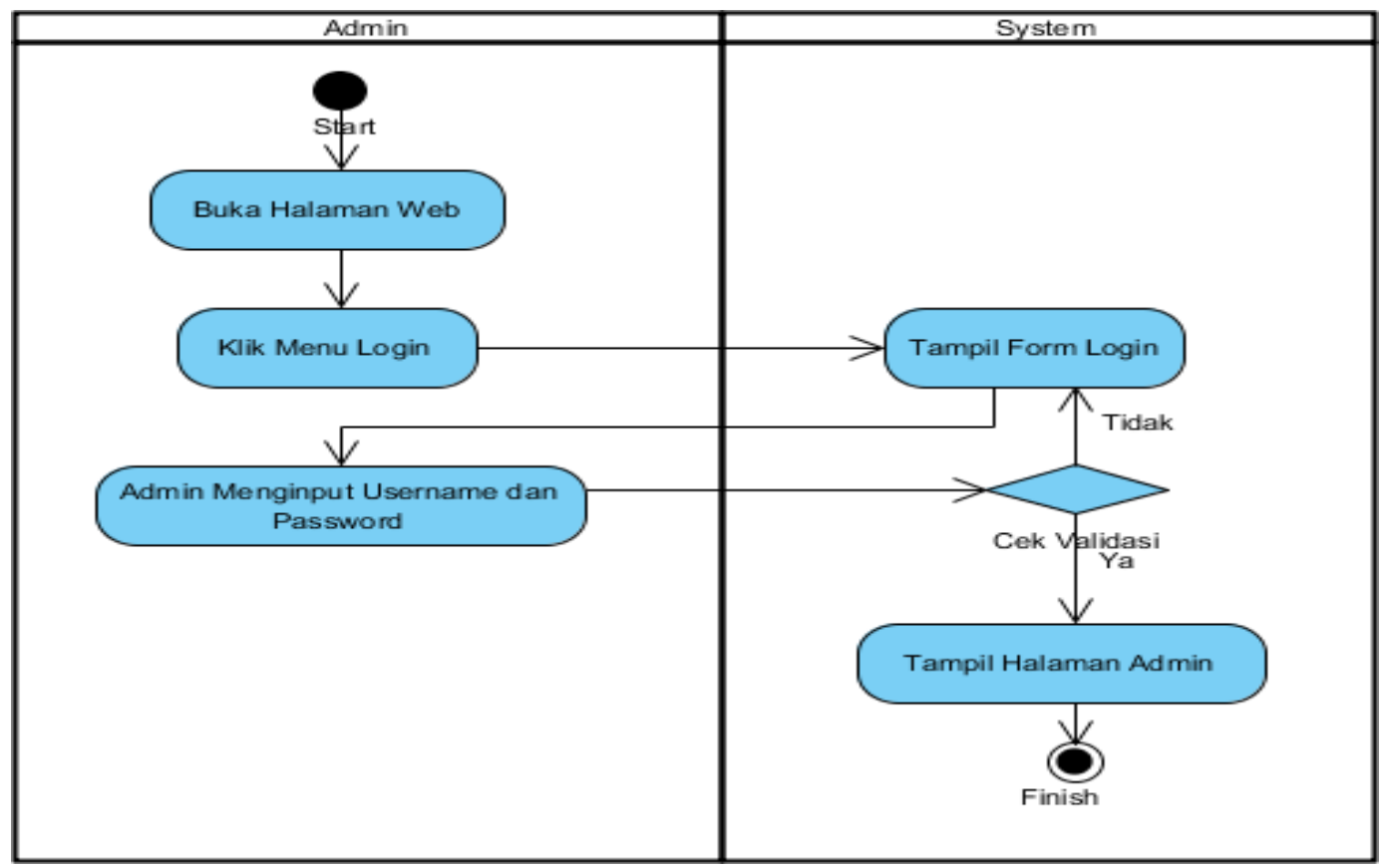

Gambar 4. Activity Diagram Use Case Login

c. Activity Diagram Use Case Aktivasi Akun Data Alumni

Activity Diagram berikut menggambarkan proses aktivasi akun data alumni terhadap isi web sebagai berikut : 


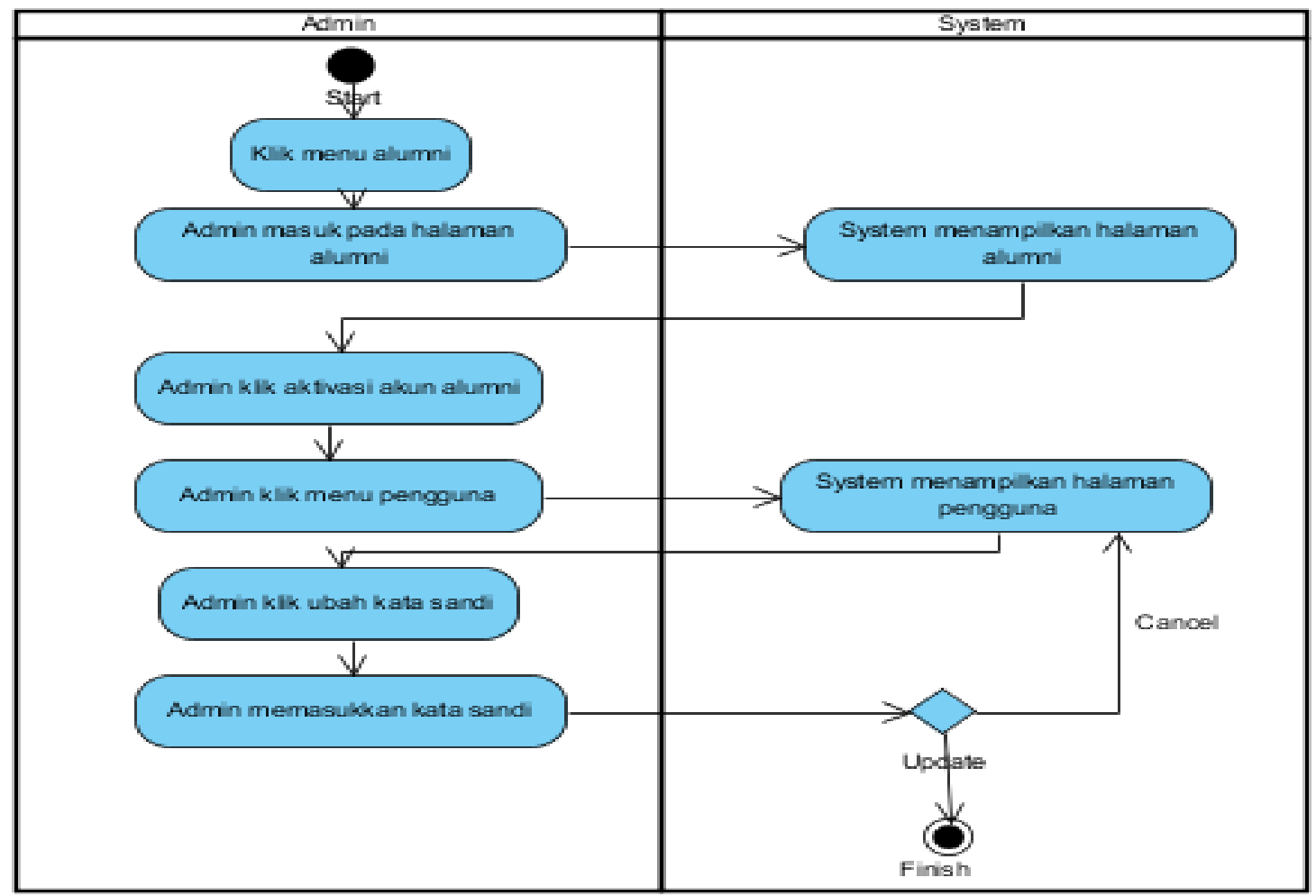

Gambar 5. Activity Diagram Use Case Aktivasi Akun Data Alumni

d. Activity Diagram Use Case Menambah Data Calon Peserta didik

Activity Diagram berikut menggambarkan proses menambah data calon peserta didik terhadap isi web sebagai berikut :

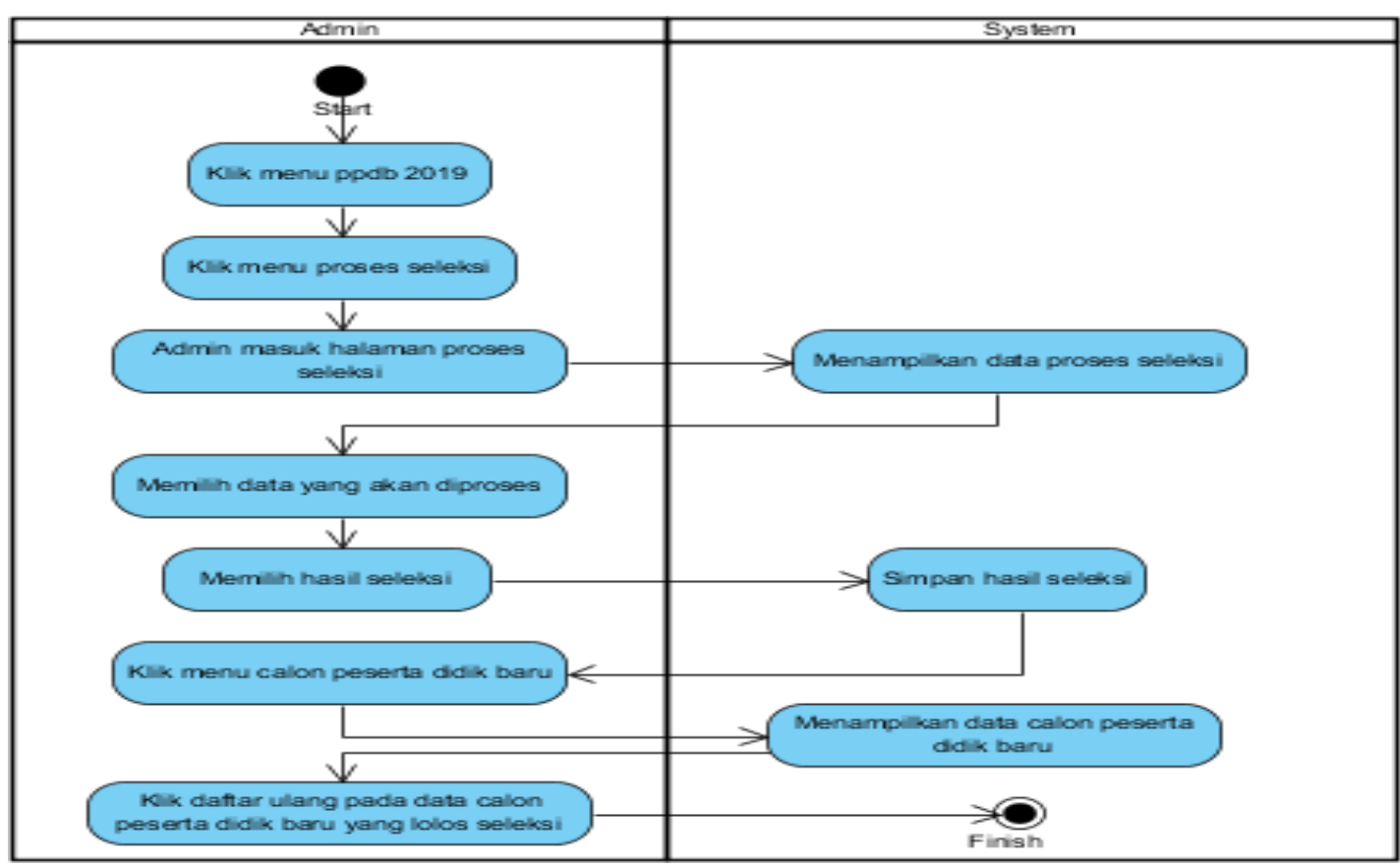

Gambar 6. Activity Diagram Use Case Menambah Data Calon Peserta didik e. Activity Diagram Use Case User

Activity Diagram berikut menggambarkan proses melihat isi web yang dilakukan oleh user adalah sebagai berikut : 


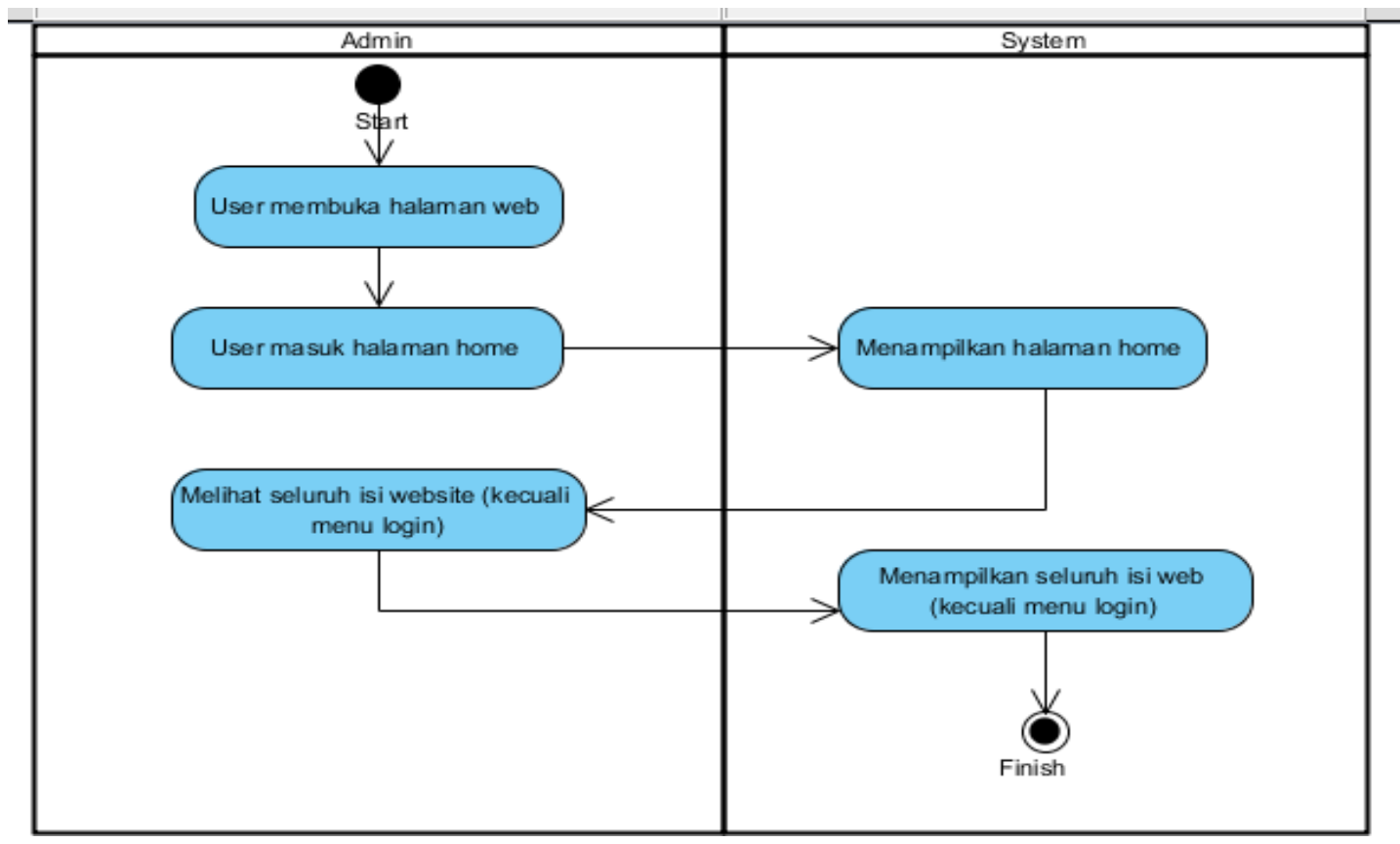

Gambar 7. Activity Diagram Use Case User

\section{f. Sequence Diagram Login}

Sequence Diagram adalah suatu diagram yang menggambarkan interaksi antar objek dan mengindikasikan komunikasi diantara objek- objek tersebut. Berikut sequence diagram pada Website Sekolah SMK.S Al Habibatain Bumiayu:

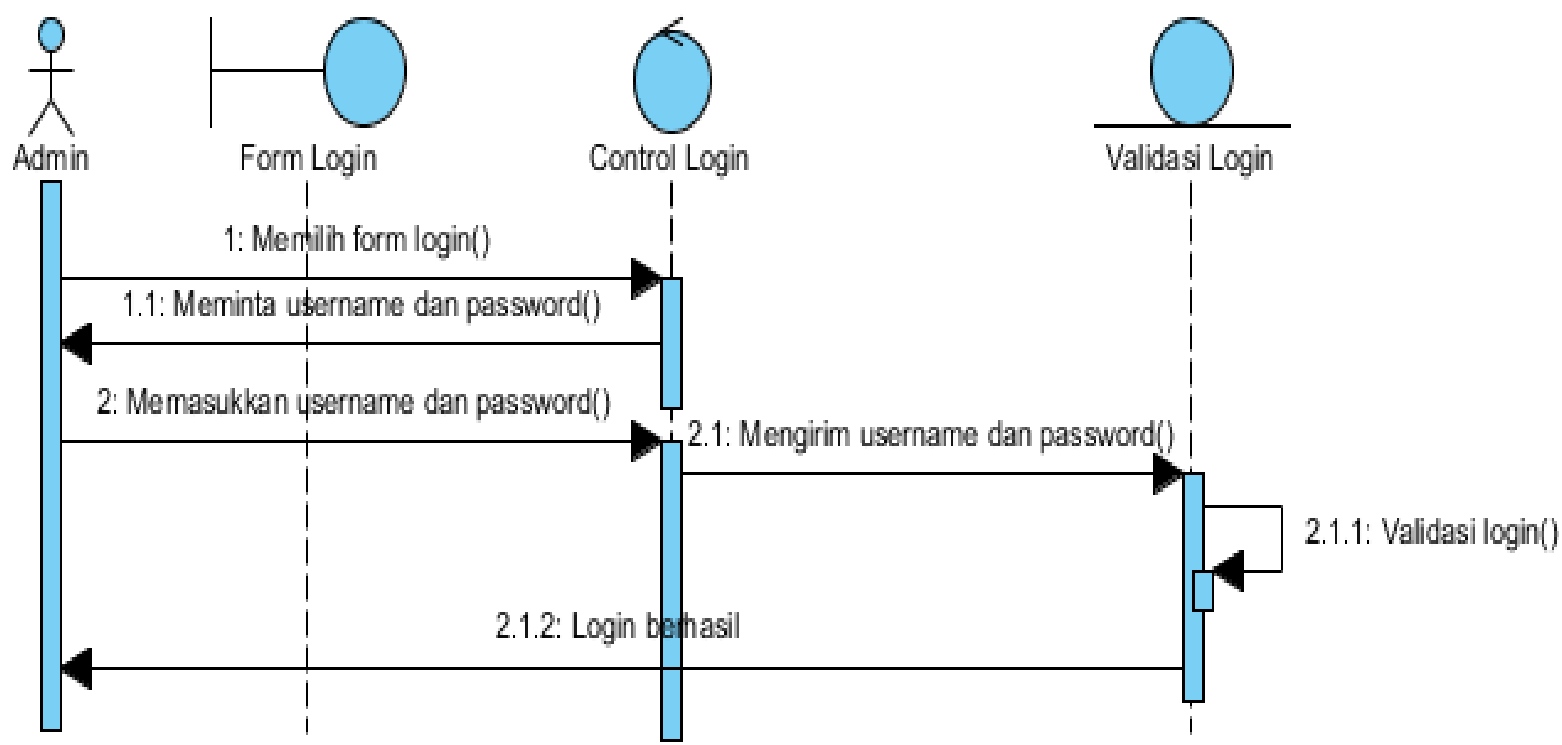

Gambar 8. Sequence Diagram Login 


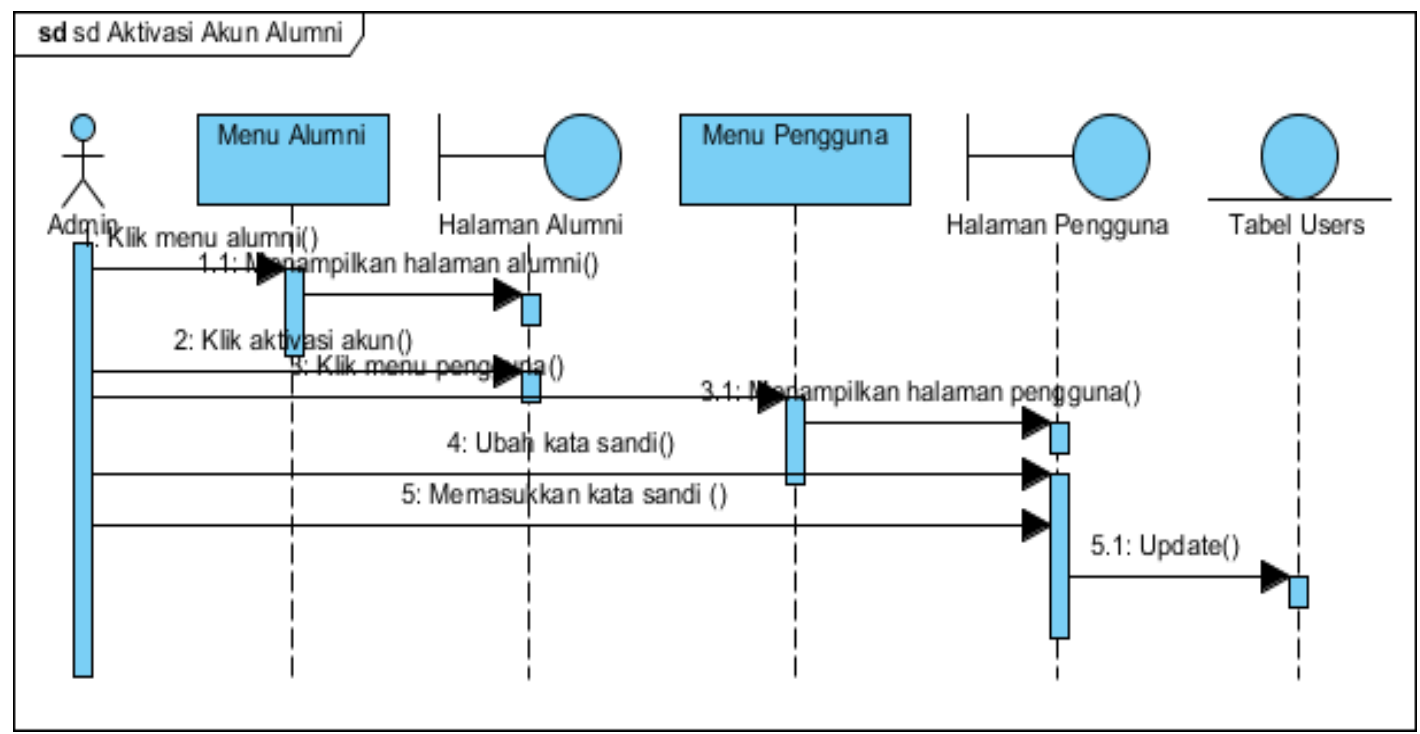

Gambar 9. Sequence Diagram Aktivitas Akun Data Alumni

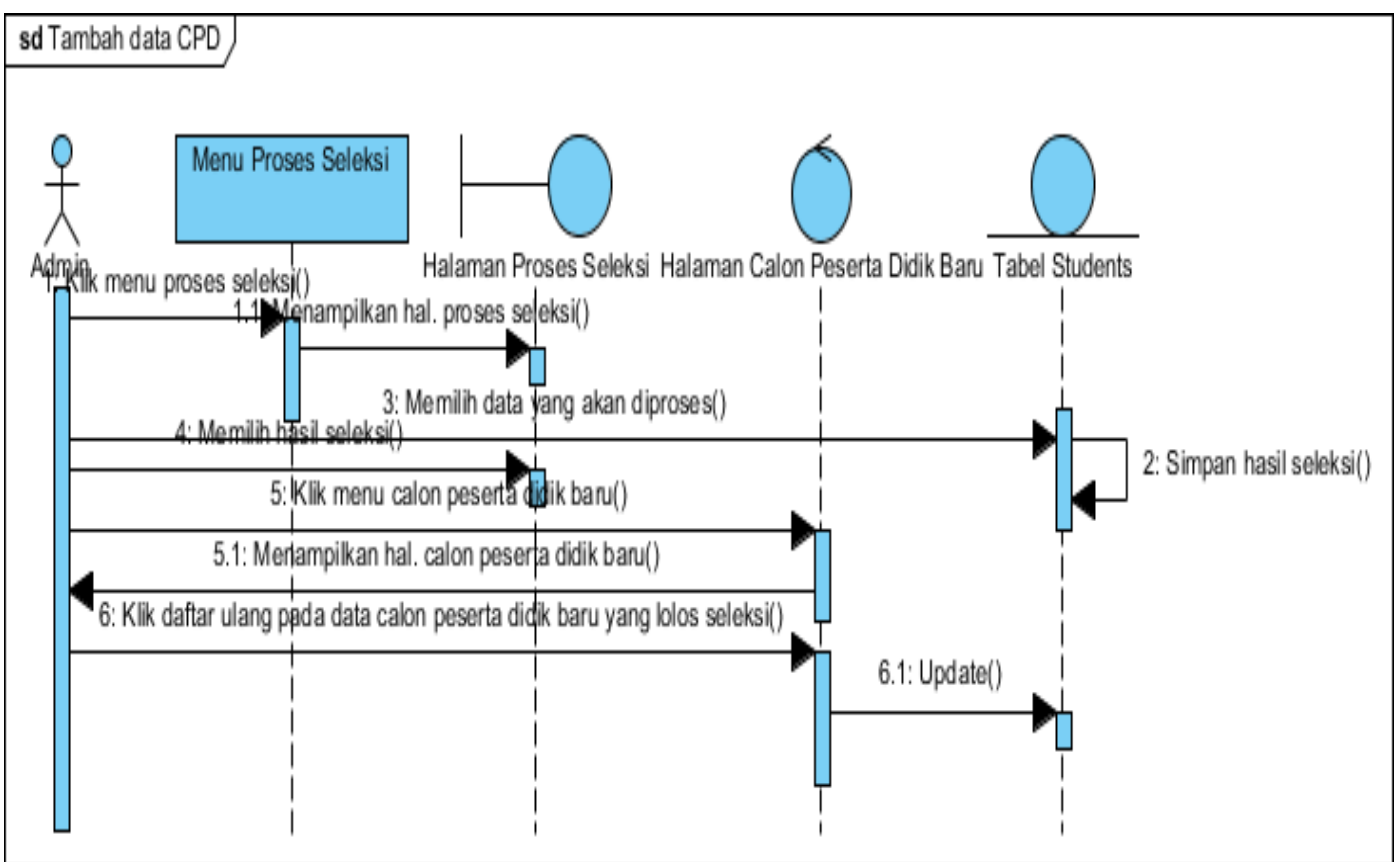

Gambar 10. Sequence Diagram Edit Peserta Didik

\section{HASIL DAN PEMBAHASAN}

Hasil dan Pembahasan merupakan isi bagian yang untama dalam penelitian, hasil dan pembahasan sebagai pertimbangan atau acuan untuk dijadikan sebuah teori, hasilnya dalam pembahasan ini berupa tampilan aplikasi yang menarik yang mudah digunakan oleh pengguna dan proses pengujian

a. Tampilan palikasi yang dihasilkan

Hasil dan pembahasan memuat hasil dari analisi desain sistem perancangan sistem berupa tampilan antarmuka sistem informasi akademik SMK-S Habibatain Bumiayu dengan user friendly sehingga memudahkan pengguna dalam menggunakan aplikasi ini. 


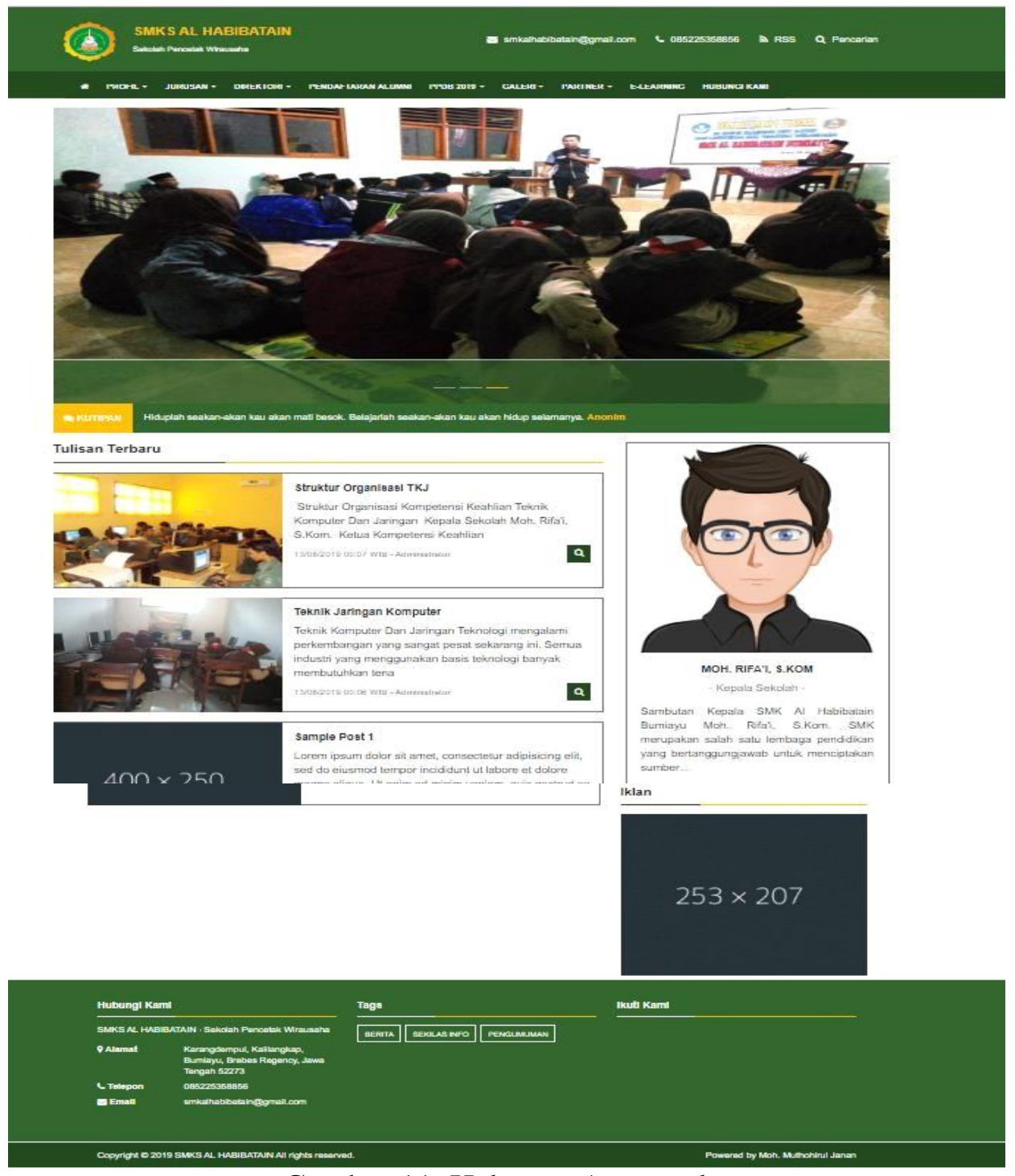

Gambar 11. Halaman Antarmuka

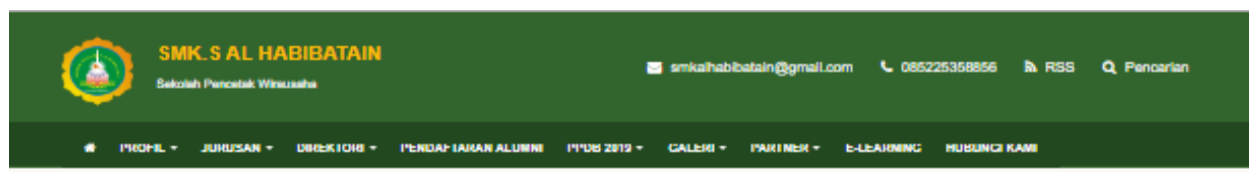

Pendaftaran Alumni

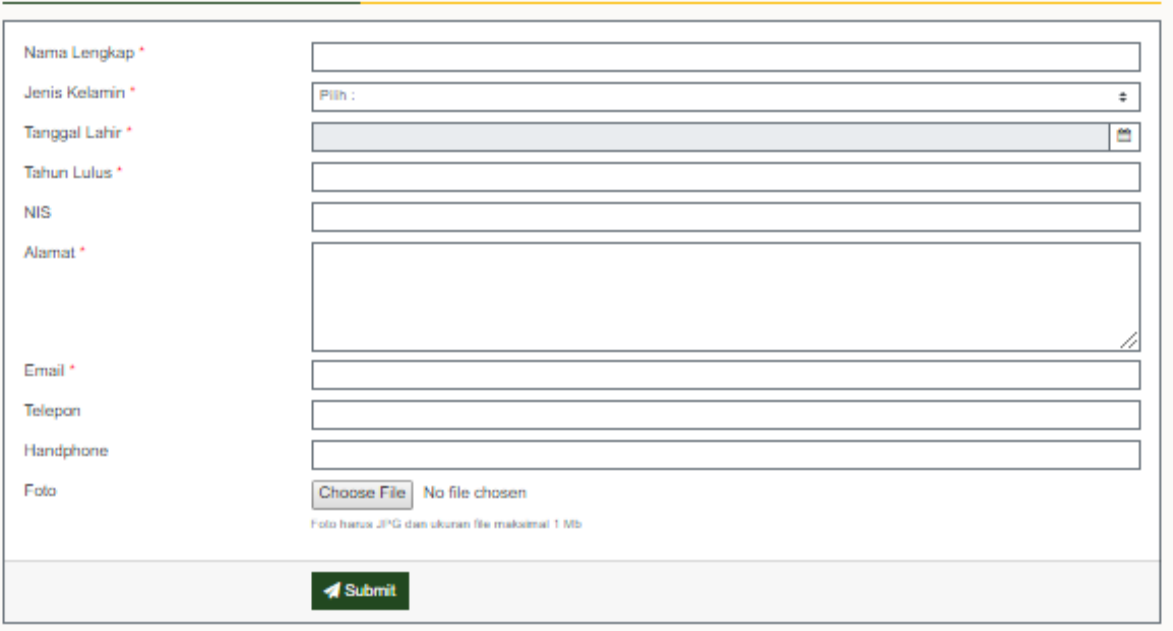

Gambar 12. Antarmuka Halaman Pendaftaran Alumni 

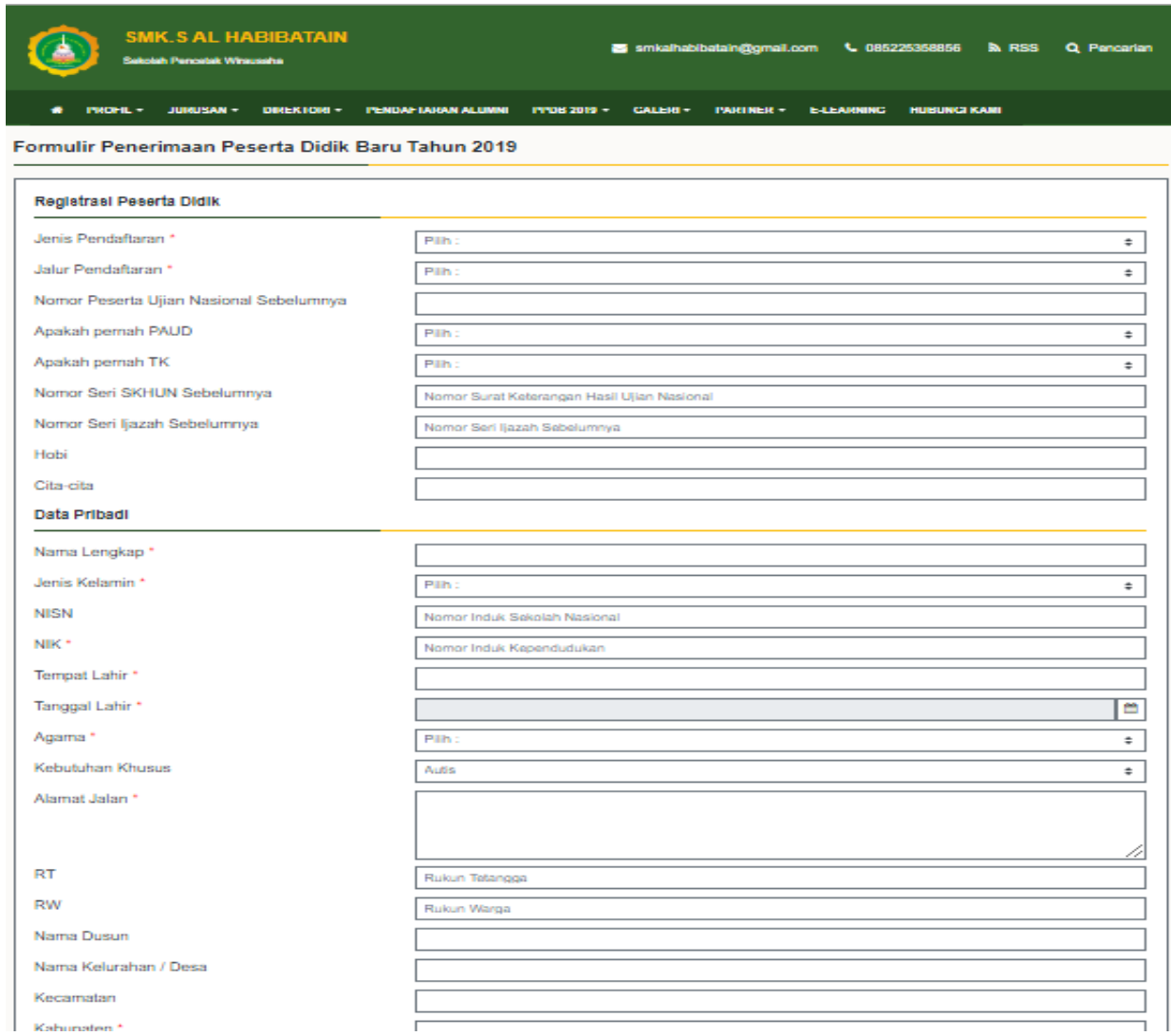

Gambar 13. Antarmuka Halaman PPDB

\section{b. Pengujian Sistem}

Pengujian sistem penerimaan peserta didik baru dan pelcakan alumni sekolah SMK.S Al HabibatainBumiayu ini adalah dengan menggunakan pengujian Blackbox.

Tabel 2. Hasil Pengujian Blackbox

\begin{tabular}{|c|c|c|c|c|}
\hline No & Form & Skenario Penguji & Hasil Yang Diharapkan & Kesimpulan \\
\hline 1. & SMK.S AL HABIBATAIN & $\begin{array}{l}\text { Mengosongkan } \\
\text { username dan } \\
\text { password lalu klik } \\
\text { tombol Sign in. }\end{array}$ & $\begin{array}{l}\text { Sistem akan menolak akses } \\
\text { login dan menampilkan } \\
\text { pesan login gagal. }\end{array}$ & Valid \\
\hline 2. & SMK.S AL HABIBATAIN & $\begin{array}{lr}\text { Memasukkan } & \\
\text { username dan } \\
\text { password yang } \\
\text { salah lalu klik } \\
\text { tombol Sign in. }\end{array}$ & $\begin{array}{l}\text { Sistem akan memverifikasi } \\
\text { akun dan akan menolak } \\
\text { login jika username dan } \\
\text { password yang dimasukkan } \\
\text { salah serta menampilkan } \\
\text { pesan login gagal. }\end{array}$ & Valid \\
\hline 3. & SMK.S AL HABIBATAIN & $\begin{array}{lr}\text { Memasukkan } & \\
\text { username dan } \\
\text { password yang } \\
\text { benar lalu klik } \\
\text { tombol Sign in. }\end{array}$ & $\begin{array}{l}\text { Sistem akan memverifikasi } \\
\text { akun dan menampilkan } \\
\text { pesan login sukses.. }\end{array}$ & Valid \\
\hline
\end{tabular}




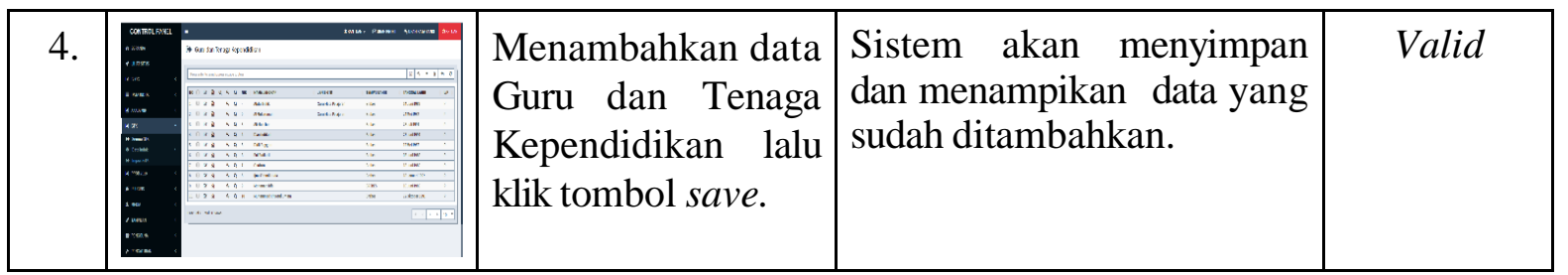

\section{KESIMPULAN} berikut:

Berdasarkan hasil penelitian dan pembahasan, maka diperoleh kesimpulan sebagai

a. Berdasarkan hasil penelitian ini para alumni lebih mudah diidentifikasi keberadaannya, misalnya : kerja dimana atau sedang kuliah dimana karena sistem yang dibagun berbasis website pengguna bisa masuk ke website dan memasukan data yang disajikan.

b. Sistem informasi penerimaan peserta didik baru sangat membantu calon siswa yang akan melakukan pendaftaran secara online karena calon peserta didik bisa langung mengakses alamat yang ada di sistem tersebut

c. Sistem ini menjadi sarana baru untuk mendekatkan antara calon peserta didik baru dan sekolah

d. Sistem penerimaan peserta didik baru berbasis website membantu tugas tata usaha dalam mengelola setiap calon pendaftar yang masuk ke SMK.

\section{DAFTAR PUSTAKA}

[1] Sugiri dan H. Saputro, Pengelolaan Database Mysql dengan PhpMyAdmin, Yogyakarta: Graha Ilmu, 2008.

[2] A. Hariyanto, Membuat Aplikasi Computer Based Text dengan PHP, MySQLi dam Bootsrap, Yogyakarta: CV. LOKOMEDIA, 2017.

[3] A. Kadir, Mudah Menjadi Programmer PHP, Yogyakarta: CV ANDI OFFSET, 2009.

[4] W. F. Kusuma, "Jurnal Teknik Informatika," Pengembangan Halaman Web Menggunakan Xml Dalam Perkembangan Web 2.O, 2015.

[5] D. S. Manne, S. Yelisetti, M. Kakarla dan D. S. Fatima, Mining VRSEC Student Learning Behaviour In Moodle System Using Datamining Techniques, p. 7, 2014.

[6] D. Puspitasari, "JurnalPilar Nusa Mandiri," Sistem Informasi Perpustakaan Sekolah Berbasis Web, vol. XII, p. 14, 2016.

[7] A. Hendini, "Jurnal Khatulistiwa Informatika," Permodelan Uml Sistem Informasi Monitoring Penjualan Stok Barang (Studi Kasus:Distro Zhezha Pontianak), 2016.

[8] Hardiyan dan Mahpud, "Jurnal Techno Nusa Mandiri," Penerapan Metode Waterfall Pada Program Aplikasi Pengolahan Nilai Online Pada Smp Islam Abaabil Tangerang, pp. 43-47, 2017.

[9] B. Sidik, "Pemrograman Web dengan PHP : Edisi Revisi Kedua,” Pemrograman, 2014.

[10] N. Utami, "Sistem informasi inventori barang pt. tissan nugraha globalindo berbasis web publikasi ilmiah," Sistem Informasi Inventori Barang Pt. Tissan Nugraha Globalindo Berbasis Web, 2018.

[11] Regi Witanto, Hanhan Hanafiah Solihin, "Jurnal Infotronik", Perancangan Sistem Penerimaan Siswa Baru Berbasis Website (Studi Kasus : SMP Plus Babussalam Bandung), Volume 1 No. 1, 2016.

[12] Susana Eviani, dkk, "Jurnal Teknologi", Sistem Informasi Penerimaan Siswa baru Berbasis Web Pada SMPN 34 Kabupaten Tebo, Vol 6 No.1, 2016 
[13] Margareta Mawang, dkk, "Jurnal Pilar Nusa Mandiri”, Rancang Bangun Sistem Informasi Pengolahan Data Persediaan Barang Berbasis Dekstop Dengan Model Waterfall, Vol 13 No.2, 2017 